\title{
Characterization of bioactive fatty acids and oxidative stability of microwave vacuum dried fish powder supplemented extruded product
}

\author{
Muhammad Faisal MANZOOR ${ }^{1,2}$ (D), Umair SHABBIR ${ }^{3}$, Syed Muneeb GILANI ${ }^{4}$, Aysha SAMEEN 5 , \\ Nazir AHMAD ${ }^{3 *}$, Rabia SIDDIQUE ${ }^{6}$, Zahoor AHMED ${ }^{2}$, Abdul QAYYUM ${ }^{7}$, Abdur REHMAN $^{8}$
}

\begin{abstract}
This study was aimed to determine the retention of bioactive fatty acids and oxidative stability of fish powder (FP) supplemented extruded products. The Labeo rohita fish meat was minced, microwave vacuum dried, and extruded. Product formulations containing FP (0-25\%) and semolina (75-100\%) were optimized using response surface methodology. The maximum bioactive fatty acids retention was $94.84 \%$ in the final product. The highest values of polyunsaturated fatty acids (PUFAs) were $87.97 \%$ and $85.66 \%$ at $25^{\circ} \mathrm{C}$ for 30 and 60 days. Maximum TBARS values were 0.42 and $0.44 \mathrm{mg} \mathrm{MDA} / \mathrm{kg}$ at $25^{\circ} \mathrm{C}$ for 0 and 30 days, respectively. The highest carbonyl contents were $6.02,7.67,9.37 \mathrm{nmol} / \mathrm{mg}$ protein for 0,30 , and 60 days of storage at $25^{\circ} \mathrm{C}$, respectively. The moderate barrel exit temperature $\left(125^{\circ} \mathrm{C}\right)$ and feed moisture contents $(20 \%)$ and high screw speed $(150 \mathrm{rpm})$, FP (25\%) exhibit the highest retention of PUFAs in a product.
\end{abstract}

Keywords: fish powder; microwave vacuum drier; thermal extrusion; oxidative stability.

Practical Application: Fish powder can be applied for the production of value-added foods and food fortification has supported the food industry to investigate various approaches for producing fish powder from multiple raw materials.

\section{Introduction}

Fish has always been used as the richest source of essential PUFAs, including n-3 and n- 6 which have beneficial effects on human health. PUFAs have the potential to address depression and other mental disorders (Ab Latif Wani \& Ara, 2015). A docosahexaenoic fatty acid is also found abundantly in fish and essential nutrients for eye development, nervous system, and brain development of the fetus (Silva et al., 2015; Fu et al., 2017). The $n-6$ such as arachidonic acid and n-3 like eicosapentaenoic acid are have been proven precursors of lipid mediator signaling molecules, named "eicosanoids," that play important roles in the regulation of inflammation (Patterson et al., 2012). The crosssectional studies conducted on human beings have shown that the patients having a higher ratio of $\mathrm{n}-6$ to $\mathrm{n}-3$ demonstrated unpleasant moods while and lower has a significant effect on good mood by probably reducing the vulnerability to depression and cardiovascular diseases (CVDs) (Berger et al., 2017). Labeo rohita (rohu) is one of the prime species of fish cultivated in Asia. It has high commercial and nutritional values due to the high amount of PUFAs and white meat (Memon et al., 2011). Rohu belongs to the carp family and is abundantly found in freshwater lakes and rivers of Pakistan, Bangladesh, India, and Thailand. It is considered one of the most popular, crucial, and economic freshwater fish.

Drying is one of the ancient methods of preserving fish meat. The need for developing dried fish powder (FP) and the formation of functional and ready-to-eat foods is growing day by day (Shaviklo et al., 2013). The quality and safety characteristics of dried fish directly depend upon the source of raw material and process applied for drying purposes (Shaviklo et al., 2011, 2012). Novel processing is further helping to prepare FP which is helpful for the storage of fish for a longer period. The microwave vacuum drying (MVD) method is a combination of both microwave and vacuum drying as it has more uniform heat transferring potential and a more energy-saving process for all kinds of foodstuffs (Cui et al., 2008). While extrusion is a multi-functional and multi-purposes thermal and mechanical cooking process widely used in food industries to exhibit higher nutrition value containing essential amino acids and essential fatty acids along with pharmaceutical applications (Li et al., 2007). The geometry of extruders, food mix composition, and processing conditions play a vital role in physiochemical and nutritional changes in food material (Zhang et al., 2014; Shahzad et al., 2020). Research studies have reported that thermal extrusion causes complete inactivation of enzymes in food unlike that of high-temperature short-time processing methods. Most of the anti-nutritional substances are destroyed in extrusion processing. Proteins and

Received 19 July, 2020

Accepted 27 Aug., 2020

${ }^{1}$ School of Food and Biological Engineering, Jiangsu University, Zhenjiang, Jiangsu, China

${ }^{2}$ School of Food Science and Engineering, South China University and Technology, Guangzhou, China

${ }^{3}$ Institute of Home and Food Sciences, Faculty of Life Sciences, Government College University, Faisalabad, Pakistan

${ }^{4}$ Department of Nutrition Science, KUHS University of Management and Technology, Sialkot, Pakistan

${ }^{5}$ National Institute of Food Science \& Technology, University of Agriculture Faisalabad, Faisalabad, Pakistan

${ }^{6}$ Department of Chemistry, Government College University Faisalabad, Faisalabad, Pakistan

${ }^{7}$ Key Laboratory of Dairy Science (Northeast Agricultural University), Ministry of Education, Harbin, PR China

${ }^{8}$ State Key Laboratory of Food Science and Technology, Jiangnan University, Wuxi, China

${ }^{\star}$ Corresponding author: drnazirahmad@gcuf.edu.pk 
starches processed through extrusion are more digestible and absorbable in the body than un-extruded products. It increases the bioavailability of amino acids and inhibits the activity of trypsin along with other growth-inhibiting substances (Singh et al., 2007; Ahmad et al., 2019).

The lipid oxidation is reduced even at high temperature and makes more absorbable in the human body. Lower temperature, residence time, and optimized mechanical shear give end product of higher quality retaining maximum omega fatty acids. Low lipid levels (less than 5\%) aids in extrusion processing and greater product stability and expansion (Kouba \& Mourot, 2011). During extrusion, most of the hydrolytic lipases are destroyed thus preventing catabolism of triglycerides into free fatty acids and glycerol. Short retention time inhibits lipid oxidation so maximum lipids get retained in the final product. Millard reaction products resulting in extrusion also act as antioxidants thus preventing lipid oxidation during extrusion (Kouba \& Mourot, 2011). In this context, the basic purpose of this research was to examine the retention and oxidative stability of essential unsaturated fatty acids of FP supplemented extruded macaroni with high PUFAs contents.

\section{Materials and methods}

\subsection{Procurement and preparation of sample}

Rohu fish (weight of $1500 \pm 150 \mathrm{~g}$ ) was used as raw and experimental material for this research. Fish was purchased from local markets, Faisalabad-Pakistan. Head, fins, tail, and viscera of fish were removed following deboning and mincing then subjected to microwave vacuum drying in a microwave vacuum dryer.

\subsection{Microwave Vacuum Drying (MVD)}

A lab-scale microwave vacuum dryer (WZD2S, Nanking Sanle, China) was used for drying fish. It had a capacity of drying fish ranging from 8 to $12 \mathrm{~kg}$ of fish under different temperatures and pressure. It was optimized to the power of $1300 \mathrm{~W}$ and operated at $2450 \mathrm{MHz}$ frequency, 90 Pascal pressure for 4.5 hours at $50^{\circ} \mathrm{C}$. The dried minced powder was preserved in polyethylene bags.

\subsection{Grinding of dried mince}

After completion of the drying process, the dried mince fish was ground to powder form using a spinning blade grinder (Duronic CG250- 250W motor, UK).

\subsection{Thermal extrusion optimization}

The twin-screw extruder was used to extrude the products. It had a screw diameter of $36 \mathrm{~mm}$ with a length to diameter ratio of 24:1. It had a temperature control zone for thermal cooking with a temperature measuring probe and also had a screw speed controller as shown in the supplementary file (Wang et al., 2017). Optimization was performed using Box Behnken Design, RSM. Optimization conditions for BET were ranging from $100-150{ }^{\circ} \mathrm{C}$, SS from 100-150 rpm, FFR from 30-90 kg/hr, FMC from 10$30 \%$ and FP from 0-25\% (Imran \& Anjum, 2014). Semolina (75-100\%) was also used for making the final product. For the convenience of experimental design, coding was used which is presented in Table 1.

\subsection{Preparation of sample for fatty acids analysis}

Total lipids of FP and final product were estimated according to AOAC Method No. 923.07 (Ogbobe \& Akano, 1993). Fatty acid methyl ester (FAME) of samples were prepared according to the method prescribed by (Carvalho \& Malcata, 2005).

\subsection{Gas chromatographic analysis}

The FAME sample of $1.0 \mu \mathrm{L}$ was injected with Helium $(1 \mathrm{~mL} / \mathrm{min})$ as a carrier gas onto the column that was programmed for operating conditions such as column oven temperature $160^{\circ} \mathrm{C}$ at 0 minutes with subsequent increase of $3^{\circ} \mathrm{C} / \mathrm{min}$ until $180^{\circ} \mathrm{C}$. The column oven temperature was increased from $180^{\circ} \mathrm{C}$ to $220^{\circ} \mathrm{C}$ at $1{ }^{\circ} \mathrm{C} / \mathrm{min}$ and was held for $7.5 \mathrm{~min}$ at $220^{\circ} \mathrm{C}$. The split ratio was $50 \%$ with injector temperature of $240{ }^{\circ} \mathrm{C}$ and detector $250^{\circ} \mathrm{C}$. The peak areas and total fatty acids composition were calculated for each sample by retention time using Varian Chem Station software.

\subsection{Retention of fatty acids}

The retention of fatty acids was calculated according to the following Equation 1:

Fatty acids retention $\%=\frac{\text { fattyacids present in product after extrusion }}{\text { fatty acids present in rawmaterial }} \times 100$

\subsection{Thiobarbituric acid reactive substances (TBARS) analysis}

Product sample ( $5 \mathrm{~g}$ ) was taken and homogenized with $11 \%$ trichloroacetic acid (TCA) for $1 \mathrm{~min}$ at $11000 \mathrm{rpm}$ (Homogenizer: IKA, Wilmington, USA) and subsequently placed in the ice bath for $1.0 \mathrm{~min}$ and then homogenized for another $1.0 \mathrm{~min}$.

Table 1. Codes and actual levels of independent variables for optimization of response factors as determined by Box-Behnken design.

\begin{tabular}{lcccc}
\hline \multicolumn{1}{c}{ Independent variables } & \multirow{2}{*}{ Units } & -1 & \multicolumn{2}{c}{ Coded levels } \\
\cline { 3 - 5 } & & ${ }^{\circ} \mathrm{C}$ & 100 & 0 \\
\hline Barrel Exit Temperature (BET) & $\mathrm{kg} / \mathrm{hr}$ & 30 & 60 & 125 \\
Feed Flow Rate (FFR) & $\mathrm{rpm}$ & 50 & 100 & 90 \\
Screw Speed (SS) & $\%$ & 10 & 20 & 150 \\
Feed Moisture Content (FMC) & $\%$ & 0 & 12.5 & 30 \\
Fish Powder (FP) & & & 25 \\
\hline
\end{tabular}


The homogenate was separated through Whatman No.1 and then added $1.0 \mathrm{~mL}$ of $20 \mathrm{mM}$ thiobarbituric acid solution to $1.0 \mathrm{~mL}$ of filtrate following incubation for $20 \mathrm{hr}$ in dark conditions at $25^{\circ} \mathrm{C}$. The absorbance value was determined at $532 \mathrm{~nm}$ through the UV-1800 spectrophotometer (Shimadzu, Kyoto, Japan). The results were calculated as $\mathrm{mg}$ of $\mathrm{MDA} / \mathrm{kg}$.

\subsection{Carbonyl contents analysis}

The carbonyl contents were determined to calculate the oxidation of protein during extrusion and storage time. A sample of $3.0 \mathrm{~g}$ was homogenized with $0.15 \mathrm{M} \mathrm{KCl}(7.4 \mathrm{pH})$ at $7100 \mathrm{rpm}$ for 90 seconds (Homogenizer: IKA, Wilmington, USA). The precipitation of protein present in the homogenate was done using $10 \%$ TCA and centrifuging at $5000 \mathrm{~g}, 4^{\circ} \mathrm{C}$ for 5 minutes (ST 16R, Thermo Scientific, Wilmington, DE). The supernatant is discarded and then $10 \mathrm{mM}$ 2, 4-dinitrophenylhydrazine (DNPH) in $2.0 \mathrm{~N} \mathrm{HCl}$ was added in the precipitate and incubated at $25^{\circ} \mathrm{C}$ for $1 \mathrm{hr}$ in the dark with gentle vortexing after every 15 minutes. The substrate reacted with DNPH was then precipitated using TCA (10\%) following centrifugation at $11000 \mathrm{~g}, 4^{\circ} \mathrm{C}$ for 10 minutes. The precipitate was then washed three times using ethanol/ ethyl acetate $(1: 1, \mathrm{v} / \mathrm{v})$ solution and solubilized with guanidine hydrochloride $(6 \mathrm{M})$ in $20 \mathrm{mM}$ sodium phosphate buffer having $\mathrm{pH}$ 6.5. Centrifuge again at $11000 \mathrm{~g}, 25^{\circ} \mathrm{C}$ for 10 minutes to remove insoluble particles. Absorbance was estimated at $370 \mathrm{~nm}$ through the UV-1800 spectrophotometer (Shimadzu, Kyoto, Japan). Carbonyl contents were estimated through the absorbance coefficient for protein hydrazones. The obtained results were expressed as nmol of carbonyl/mg of protein.

\subsection{Sensory evaluation}

A trained panel of judges evaluated the product for sensory evaluation using a 9-point hedonic scale (Civille \& Carr, 2015). Color, flavor, and overall acceptability were evaluated after product development and the same after a storage period of 60 days interval.

\subsection{Statistical analysis}

The optimization of microwave and extrusion conditions was performed through RSM using Design Expert 11 software of statistics. The experiment analyses were conducted through the method of Montgomery (1991). All experiments were conducted in triplicates and average values were considered as mean values. The significance of values was calculated statistically through mean using Analysis of variance (ANOVA) at the probability of 0.05 through MATLAB $^{\circledast}$ (Ver. 7.9.0) software (Mathworks, Inc., Natick, USA).

\section{Results and discussion}

\subsection{Results}

The powder obtained from fish under microwave vacuum drying contained $9.64 \pm 32 \%$ total lipids that non-significantly changed during the drying process. The PUFAs that were determined and measured in this study were C18: 2 n-6, C18: 3 n-3, C20:3 n-7, C24:4 n-6, C25:5 n-3, and C22:6 n-3, while the MUFAs were
C16:1 n-7, C18:1 n-9, and C20:1 n-9. The SFAs were C14:0, C15:0, C16:0, C17:0, C18:0, C19:0, and C20:0. The PUFAs, MUFAs, and SFAs were $14.30 \pm 1.72,27.60 \pm 1.32$ and $49.86 \pm 2.37 \%$ in FP obtained from the drying process. The PUFA retention after different extrusion conditions is presented in Table 2 . The highest PUFAs contents $(607 \pm 8 \mathrm{mg}$ ) were found in product with $25 \%$ FP extruded under BET $\left(125^{\circ} \mathrm{C}\right)$, SS (150 rpm), FFR $(60 \mathrm{~kg} / \mathrm{hr})$, FMC (20\%) conditions and minimum PUFAs (320 $\pm 2 \mathrm{mg})$ were present in a product without FP extruded under BET $\left(125^{\circ} \mathrm{C}\right)$, SS (50 rpm), FFR (60 kg/hr), FMC (20\%) as shown in Table 2. The maximum PUFAs retention was $94.84 \%$ under optimizing conditions of BET $\left(125^{\circ} \mathrm{C}\right)$, SS $(150 \mathrm{rpm})$, FFR $(60 \mathrm{~kg} / \mathrm{hr})$, FMC $(20 \%)$ and FP (25\%) and in final products, while the minimum PUFAs retention (80\%) was observed in a product at BET $\left(125^{\circ} \mathrm{C}\right)$, SS (50 rpm), FFR $(60 \mathrm{~kg} / \mathrm{hr}), \mathrm{FMC}(20 \%)$ and FP (0\%). The supplementary file shows how a response variable (PUFAs) relates to predictor variables. It shows that the response is connected to produce contour lines of constant responses.

The effect of thermal processing on MUFAs and SFAs are shown in Table 3. The results show that the maximum MUFAs retention was $96.48 \%$ under optimizing conditions of BET $\left(125^{\circ} \mathrm{C}\right), \mathrm{SS}(150 \mathrm{rpm}), \mathrm{FFR}(60 \mathrm{~kg} / \mathrm{hr}), \mathrm{FMC}(20 \%)$ and FP $(25 \%)$ in final products while minimum MUFAs retention (66\%) was observed at $125^{\circ} \mathrm{C} \mathrm{BET}, 50 \mathrm{rpm} \mathrm{SS}, 60 \mathrm{~kg} / \mathrm{hr}$ FFR, 20\% FMC and $0 \%$ FP. Maximum SFAs contents $(1.55 \pm 0.007 \%)$ were observed in a final product that was extruded under conditions of BET $\left(150{ }^{\circ} \mathrm{C}\right)$, SS $(100 \mathrm{rpm})$, FFR $(60 \mathrm{~kg} / \mathrm{hr})$, FMC (20\%) and FP (25\%). The minimum SFAs contents were found to be $0.214 \%$ under $100^{\circ} \mathrm{C}$ BET, $100 \mathrm{rpm} \mathrm{SS}, 60 \mathrm{~kg} / \mathrm{hr}$ FFR, 20\% FMC and $0 \%$ FP. BET was the most independent parameter affecting the retention of PUFAs. A trend in PUFAs decrease was observed with increasing temperature and decreasing moisture content while an increasing trend in PUFAs was observed with increasing SS and FP as shown in Figure 1.

Highest values of PUFAs retention (87.97\% and $85.66 \%$ ) at a storage temperature of $25{ }^{\circ} \mathrm{C}$ for 30 and 60 days were observed in a product extruded under processing conditions of BET $\left(125^{\circ} \mathrm{C}\right)$, SS (150rpm), FFR (60 kg/hr), FMC (20\%) and FP (25\%). While the minimum PUFAs values (85.80\% and $83.87 \%$ ) were observed at $25^{\circ} \mathrm{C}$ storage temperature for 30 and 60 days in product processed at BET $\left(125^{\circ} \mathrm{C}\right)$, SS $(150 \mathrm{rpm})$, FFR (90 kg/hr) and FMC (20\%) and FP (12.5\%) as shown in Table 2 . The minimum value of MUFAs ( $55 \pm 1$ and $56 \pm 1 \mathrm{mg}$ ) at 30 and 60 days storage were found at $125^{\circ} \mathrm{C} \mathrm{BET,} 50 \mathrm{rpm}$ SS, $60 \mathrm{~kg} / \mathrm{hr}$ FFR, 20\% FMC and 0\% FP and minimum SFAs $(214 \pm 2$ and $216 \pm 1 \mathrm{mg})$ at 30 and 60 days storage were present at $125^{\circ} \mathrm{C} \mathrm{BET}, 100 \mathrm{rpm} \mathrm{SS}, 60 \mathrm{~kg} / \mathrm{hr}$ FFR, 30\% FMC and $0 \% \mathrm{FP}$ as shown in Table 3.

Oxidative stability of the product was measured by determining the TBARS and carbonyl contents are presented in Table 4. The highest TBARS values at processing conditions of BET $\left(125^{\circ} \mathrm{C}\right)$, SS (150 rpm), FFR (90 kg/hr) and FMC (20\%) and $\mathrm{FP}(12.5 \%)$ was 0.42 and $0.44 \mathrm{mg} \mathrm{MDA} / \mathrm{kg}$ at $25^{\circ} \mathrm{C}$ storage temperature for 0 and 30 days respectively while $0.55 \mathrm{mg}$ $\mathrm{MDA} / \mathrm{kg}$ at 60 days storage were in product extruded at BET $\left(125^{\circ} \mathrm{C}\right)$, SS (100 rpm), FFR (30\%), FMC (20\%) and FP (25\%). The highest carbonyl contents of $6.02,7.67,9.37 \mathrm{nmol} / \mathrm{mg}$ protein 
Table 2. Effect of extrusion processing conditions on retention of polyunsaturated fatty acids at different storage intervals.

\begin{tabular}{|c|c|c|c|c|c|c|c|c|}
\hline \multirow{3}{*}{$\begin{array}{c}\text { Extrusion } \\
\text { processing run }\end{array}$} & \multicolumn{5}{|c|}{ Independent variables } & \multirow{2}{*}{\multicolumn{3}{|c|}{$\begin{array}{c}\text { Dependent variable } \\
\text { PUFAs }(\mathrm{mg} / 100 \mathrm{~g})\end{array}$}} \\
\hline & \multirow{2}{*}{$\begin{array}{l}\text { Barrel Exit } \\
\text { Temp. (BET) }\end{array}$} & \multirow{2}{*}{$\begin{array}{c}\text { Screw Speed } \\
\text { (SS) }\end{array}$} & \multirow{2}{*}{$\begin{array}{l}\text { Feed Flow } \\
\text { Rate (FFR) }\end{array}$} & \multirow{2}{*}{$\begin{array}{c}\text { Feed Moisture } \\
\text { Content } \\
\text { (FMC) }\end{array}$} & \multirow{2}{*}{$\begin{array}{c}\text { Fish Powder } \\
\text { (FP) }\end{array}$} & & & \\
\hline & & & & & & 0 Day & 30 Days & 60 Days \\
\hline 1 & $150(1)$ & $150(1)$ & $60(0)$ & $20(0)$ & $12.5(0)$ & $444 \pm 1^{\mathrm{cd}}$ & $391 \pm 3^{\mathrm{fg}}$ & $385 \pm 5^{\mathrm{fg}}$ \\
\hline 2 & $125(0)$ & $150(1)$ & $60(0)$ & $20(0)$ & $25(1)$ & $607 \pm 8^{\mathrm{a}}$ & $534 \pm 6^{\mathrm{b}}$ & $520 \pm 2^{b}$ \\
\hline $3\left(C_{1}\right)$ & $125(0)$ & $100(0)$ & $60(0)$ & $20(0)$ & $12.5(0)$ & $460 \pm 6^{c}$ & $410 \pm 3^{\mathrm{ef}}$ & $401 \pm 3^{\mathrm{f}}$ \\
\hline 4 & $150(1)$ & $100(0)$ & $60(0)$ & $30(1)$ & $12.5(0)$ & $408 \pm 9^{\text {ef }}$ & $360 \pm 2^{\mathrm{h}}$ & $345 \pm 4^{\mathrm{hi}}$ \\
\hline 5 & $100(-1)$ & $100(0)$ & $60(0)$ & $20(0)$ & $0(-1)$ & $380 \pm 7^{g}$ & $340 \pm 1^{\mathrm{i}}$ & $329 \pm 1^{j}$ \\
\hline 6 & $100(-1)$ & $150(1)$ & $60(0)$ & $20(0)$ & $12.5(0)$ & $512 \pm 9^{\mathrm{b}}$ & $452 \pm 2^{\text {cd }}$ & $440 \pm 4^{\mathrm{d}}$ \\
\hline 7 & $125(0)$ & $150(1)$ & $30(-1)$ & $20(0)$ & $12.5(0)$ & $490 \pm 8^{\mathrm{bc}}$ & $433 \pm 5^{\text {de }}$ & $424 \pm 2^{\mathrm{e}}$ \\
\hline 8 & $125(0)$ & $50(-1)$ & $60(0)$ & $10(-1)$ & $12.5(0)$ & $409 \pm 4^{\mathrm{ef}}$ & $352 \pm 3^{\mathrm{h}}$ & $346 \pm 4^{\mathrm{hi}}$ \\
\hline 9 & $150(1)$ & $100(0)$ & $60(0)$ & $20(0)$ & $0(-1)$ & $353 \pm 7^{\mathrm{h}}$ & $308 \pm 6^{\mathrm{lm}}$ & $303 \pm 1^{\mathrm{m}}$ \\
\hline 10 & $125(0)$ & $100(0)$ & $60(0)$ & $30(1)$ & $25(1)$ & $539 \pm 1^{\mathrm{b}}$ & $471 \pm 3^{c}$ & $461 \pm 2^{c}$ \\
\hline 11 & $125(0)$ & $100(0)$ & $90(1)$ & $10(-1)$ & $12.5(0)$ & $447 \pm 6^{\mathrm{cd}}$ & $386 \pm 2^{\mathrm{fg}}$ & $379 \pm 5^{g}$ \\
\hline $12\left(C_{2}\right)$ & $125(0)$ & $100(0)$ & $60(0)$ & $20(0)$ & $12.5(0)$ & $455 \pm 3^{\mathrm{cd}}$ & $401 \pm 2^{\mathrm{f}}$ & $391 \pm 3^{\mathrm{fg}}$ \\
\hline 13 & $125(0)$ & $150(1)$ & $60(0)$ & $30(1)$ & $12.5(0)$ & $508 \pm 5^{\mathrm{b}}$ & $445 \pm 5^{\mathrm{cd}}$ & $436 \pm 2^{d}$ \\
\hline 14 & $125(0)$ & $100(0)$ & $60(0)$ & $10(-1)$ & $25(1)$ & $505 \pm 9^{b}$ & $445 \pm 2^{\mathrm{cd}}$ & $436 \pm 5^{d}$ \\
\hline 15 & $125(0)$ & $100(0)$ & $30(-1)$ & $20(0)$ & $0(-1)$ & $360 \pm 3^{\mathrm{h}}$ & $319 \pm 1^{\mathrm{k}}$ & $311 \pm 2^{11}$ \\
\hline 16 & $100(-1)$ & $100(0)$ & $60(0)$ & $10(-1)$ & $12.5(0)$ & $411 \pm 5^{\mathrm{ef}}$ & $360 \pm 3^{\mathrm{h}}$ & $354 \pm 2^{\mathrm{h}}$ \\
\hline 17 & $100(-1)$ & $100(0)$ & $30(-1)$ & $20(0)$ & $12.5(0)$ & $427 \pm 5^{\mathrm{de}}$ & $371 \pm 2^{\mathrm{gh}}$ & $366 \pm 3^{g h}$ \\
\hline 18 & $150(1)$ & $100(0)$ & $90(1)$ & $20(0)$ & $12.5(0)$ & $394 \pm 1^{\mathrm{fg}}$ & $344 \pm 2^{\mathrm{hi}}$ & $338 \pm 5^{\mathrm{i}}$ \\
\hline 19 & $125(0)$ & $50(-1)$ & $60(0)$ & $20(0)$ & $0(-1)$ & $320 \pm 2^{\mathrm{k}}$ & $285 \pm 5^{\mathrm{n}}$ & $277 \pm 4^{\circ}$ \\
\hline 20 & $125(0)$ & $100(0)$ & $60(0)$ & $10(-1)$ & $0(-1)$ & $363 \pm 1^{\mathrm{gh}}$ & $324 \pm 1^{\mathrm{jk}}$ & $316 \pm 2^{\mathrm{kl}}$ \\
\hline 21 & $125(0)$ & $100(0)$ & $90(1)$ & $20(0)$ & $25(1)$ & $527 \pm 3^{b}$ & $462 \pm 3^{c}$ & $451 \pm 5^{c d}$ \\
\hline 22 & $125(0)$ & $150(1)$ & $60(0)$ & $20(0)$ & $0(-1)$ & $382 \pm 5^{g}$ & $338 \pm 2^{\mathrm{i}}$ & $334 \pm 1^{\mathrm{ij}}$ \\
\hline 23 & $125(0)$ & $100(0)$ & $90(1)$ & $30(1)$ & $12.5(0)$ & $465 \pm 2^{\mathrm{c}}$ & $419 \pm 4^{\mathrm{e}}$ & $397 \pm 2^{\mathrm{f}}$ \\
\hline $24\left(C_{3}\right)$ & $125(0)$ & $100(0)$ & $60(0)$ & $20(0)$ & $12.5(0)$ & $459 \pm 7^{c}$ & $405 \pm 2^{\mathrm{f}}$ & $390 \pm 4^{\mathrm{fg}}$ \\
\hline 25 & $100(-1)$ & $100(0)$ & $90(1)$ & $20(0)$ & $12.5(0)$ & $433 \pm 2^{\mathrm{de}}$ & $387 \pm 3^{\mathrm{fg}}$ & $375 \pm 2^{g h}$ \\
\hline $26\left(C_{4}\right)$ & $125(0)$ & $100(0)$ & $60(0)$ & $20(0)$ & $12.5(0)$ & $452 \pm 5^{c d}$ & $405 \pm 2^{\mathrm{f}}$ & $392 \pm 4^{\mathrm{fg}}$ \\
\hline 27 & $125(0)$ & $50(-1)$ & $90(1)$ & $20(0)$ & $12.5(0)$ & $411 \pm 1^{\mathrm{ef}}$ & $369 \pm 3^{\mathrm{gh}}$ & $357 \pm 6^{\mathrm{h}}$ \\
\hline 28 & $125(0)$ & $150(1)$ & $60(0)$ & $10(-1)$ & $12.5(0)$ & $466 \pm 2^{c}$ & $409 \pm 2^{\mathrm{ef}}$ & $401 \pm 4^{\mathrm{f}}$ \\
\hline 29 & $125(0)$ & $100(0)$ & $30(-1)$ & $20(0)$ & $25(1)$ & $514 \pm 7^{\mathrm{b}}$ & $459 \pm 2^{c}$ & $438 \pm 2^{d}$ \\
\hline 30 & $125(0)$ & $100(0)$ & $60(0)$ & $30(1)$ & $0(-1)$ & $390 \pm 2^{\mathrm{fg}}$ & $343 \pm 1^{\mathrm{hi}}$ & $340 \pm 1^{\mathrm{i}}$ \\
\hline $31\left(C_{5}\right)$ & $125(0)$ & $100(0)$ & $60(0)$ & $20(0)$ & $12.5(0)$ & $455 \pm 3^{\text {cd }}$ & $405 \pm 5^{f}$ & $394 \pm 3^{\mathrm{fg}}$ \\
\hline 32 & $100(-1)$ & $100(0)$ & $60(0)$ & $30(1)$ & $12.5(0)$ & $449 \pm 2^{\text {cd }}$ & $391 \pm 3^{\mathrm{fg}}$ & $387 \pm 5^{\mathrm{fg}}$ \\
\hline 33 & $150(1)$ & $100(0)$ & $60(0)$ & $20(0)$ & $25(1)$ & $470 \pm 1^{\mathrm{c}}$ & $414 \pm 3^{\mathrm{ef}}$ & $405 \pm 7^{\mathrm{f}}$ \\
\hline 34 & $125(0)$ & $50(-1)$ & $60(0)$ & $20(0)$ & $25(1)$ & $497 \pm 4^{\mathrm{bc}}$ & $436 \pm 6^{\mathrm{d}}$ & $422 \pm 4^{\mathrm{e}}$ \\
\hline 35 & $100(-1)$ & $50(-1)$ & $60(0)$ & $20(0)$ & $12.5(0)$ & $418 \pm 2^{\mathrm{e}}$ & $369 \pm 2^{\mathrm{gh}}$ & $357 \pm 1^{\mathrm{h}}$ \\
\hline 36 & $150(1)$ & $100(0)$ & $30(-1)$ & $20(0)$ & $12.5(0)$ & $392 \pm 1^{\mathrm{fg}}$ & $344 \pm 1^{\mathrm{hi}}$ & $340 \pm 2^{\mathrm{i}}$ \\
\hline 37 & $150(1)$ & $100(0)$ & $60(0)$ & $10(-1)$ & $12.5(0)$ & $403 \pm 5^{\mathrm{f}}$ & $358 \pm 4^{\mathrm{h}}$ & $348 \pm 3^{\text {hi }}$ \\
\hline 38 & $125(0)$ & $100(0)$ & $90(1)$ & $20(0)$ & $0(-1)$ & $348 \pm 2^{\mathrm{hi}}$ & $311 \pm 3^{11}$ & $301 \pm 2^{\mathrm{m}}$ \\
\hline $39\left(\mathrm{C}_{6}\right)$ & $125(0)$ & $100(0)$ & $60(0)$ & $20(0)$ & $12.5(0)$ & $447 \pm 6^{\mathrm{cd}}$ & $399 \pm 2^{\mathrm{f}}$ & $388 \pm 5^{\mathrm{fg}}$ \\
\hline 40 & $100(-1)$ & $100(0)$ & $60(0)$ & $20(0)$ & $25(1)$ & $540 \pm 3^{\mathrm{b}}$ & $475 \pm 2^{c}$ & $466 \pm 5^{c}$ \\
\hline 41 & $125(0)$ & $150(1)$ & $90(1)$ & $20(0)$ & $12.5(0)$ & $470 \pm 4^{\mathrm{c}}$ & $426 \pm 1^{\mathrm{de}}$ & $401 \pm 1^{\mathrm{f}}$ \\
\hline 42 & $150(1)$ & $50(-1)$ & $60(0)$ & $20(0)$ & $12.5(0)$ & $388 \pm 3^{\mathrm{fg}}$ & $338 \pm 5^{\mathrm{i}}$ & $327 \pm 3^{j}$ \\
\hline 43 & $125(0)$ & $50(-1)$ & $30(-1)$ & $20(0)$ & $12.5(0)$ & $422 \pm 1^{\mathrm{e}}$ & $368 \pm 2^{\mathrm{gh}}$ & $366 \pm 3^{\text {gh }}$ \\
\hline 44 & $125(0)$ & $100(0)$ & $30(-1)$ & $10(-1)$ & $12.5(0)$ & $429 \pm 5^{\mathrm{de}}$ & $373 \pm 3^{\mathrm{gh}}$ & $363 \pm 1^{\text {gh }}$ \\
\hline 45 & $125(0)$ & $100(0)$ & $30(-1)$ & $30(1)$ & $12.5(0)$ & $466 \pm 2^{c}$ & $409 \pm 6^{\mathrm{ef}}$ & $401 \pm 5^{f}$ \\
\hline 46 & $125(0)$ & $50(-1)$ & $60(0)$ & $30(1)$ & $12.5(0)$ & $419 \pm 6^{\mathrm{e}}$ & $364 \pm 3^{\text {gh }}$ & $357 \pm 2^{\mathrm{h}}$ \\
\hline
\end{tabular}

$\mathrm{C}_{1}, \mathrm{C}_{2}, \mathrm{C}_{3}, \mathrm{C}_{4}, \mathrm{C}_{5}, \mathrm{C}_{6}$ are the centre points where extrusion processing was applied. Different superscripts letters indicate the significance difference ( $\left.\mathrm{p} \leq 0.05\right)$ within the rows and columns. BET = Barrel Exit Temp; SS = Screw Speed; FFR = Feed Flow Rate; FMC = Feed Moisture Content; FP = Fish Powder; PUFAs = polyunsaturated fatty acids. 
Table 3. Effect of extrusion processing conditions on retention of SFAs and MUFAs at different storage intervals.

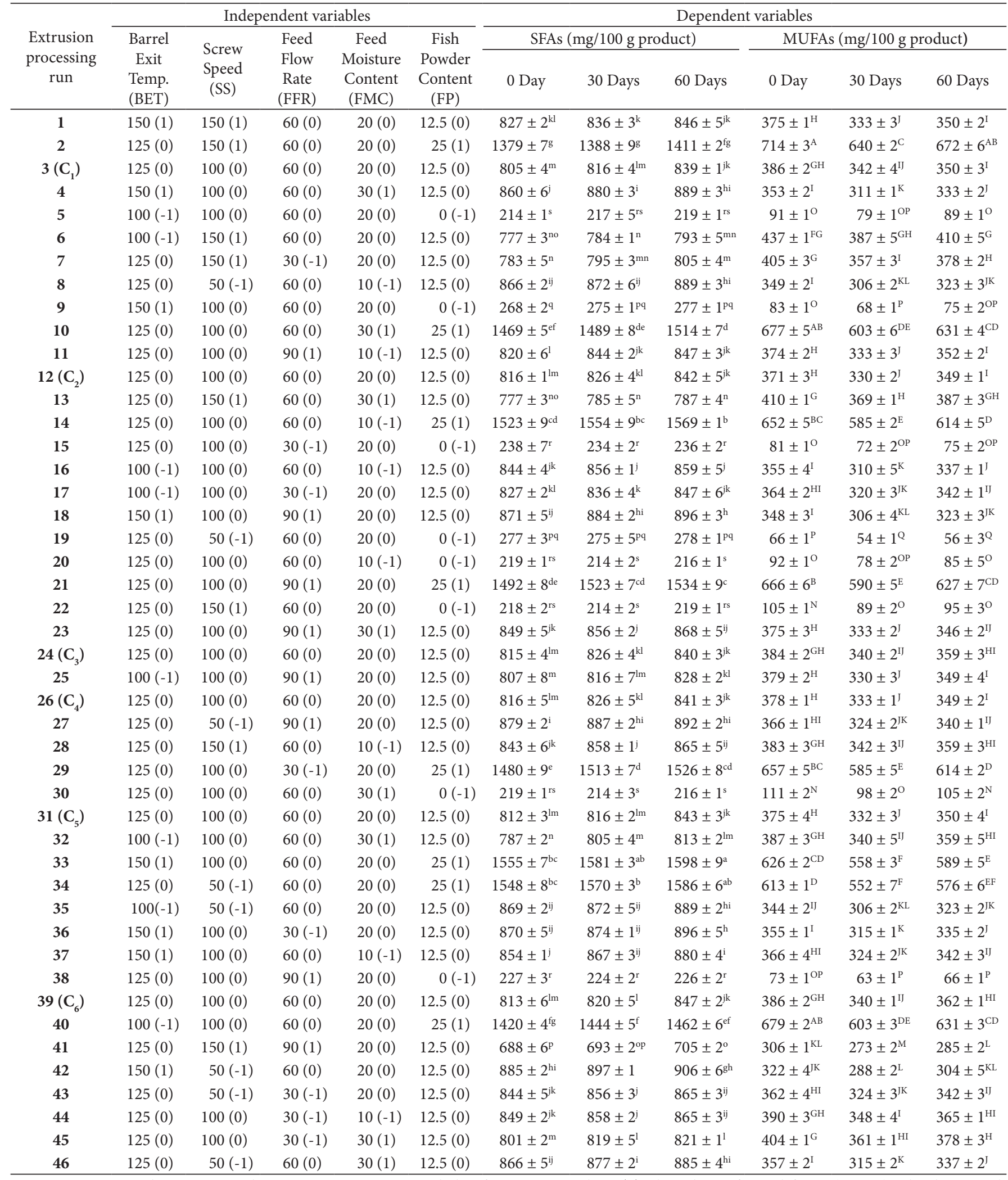

$\mathrm{C}_{1}, \mathrm{C}_{2}, \mathrm{C}_{3}, \mathrm{C}_{4} \mathrm{C}_{5}, \mathrm{C}_{6}$ are the centre points where extrusion processing was applied. Different superscripts letters ${ }^{(\mathrm{a}-\mathrm{s})}$ indicate the significance difference $(\mathrm{p} \leq 0.05)$ within the rows and columns within SFAs. Different superscripts letters ${ }^{(A-Q)}$ indicate the significance difference $(\mathrm{p} \leq 0.05)$ within the rows and columns within MUFAs. BET $=$ Barrel Exit Temp; SS $=$ Screw Speed; FFR = Feed Flow Rate; FMC = Feed Moisture Content; FP = Fish Powder; SFAs = saturated fatty acids; MUFAs = monounsaturated fatty acids. 
A

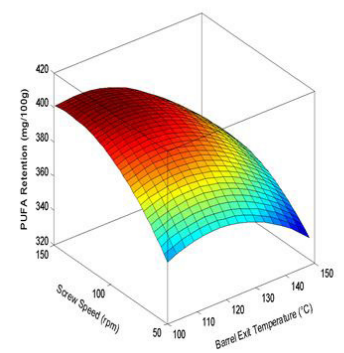

$\mathrm{F}$

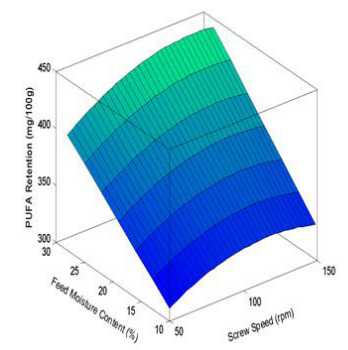

B

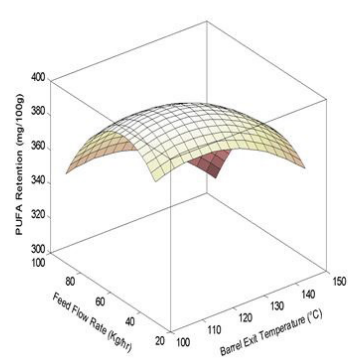

G

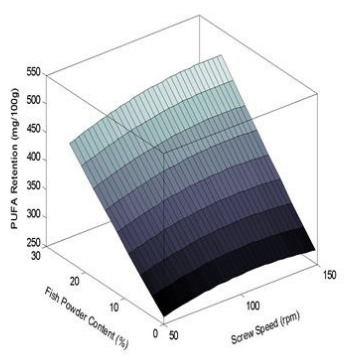

c

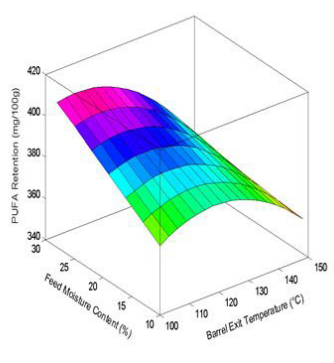

H

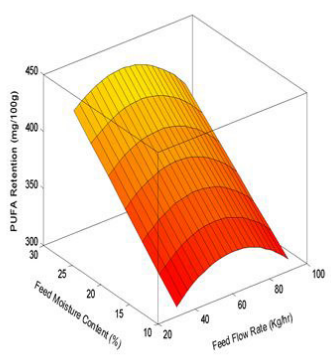

D

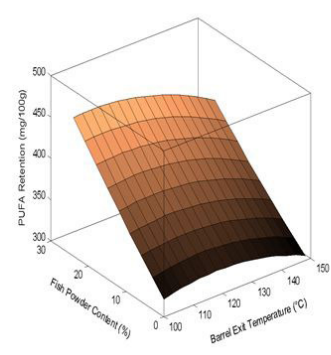

।

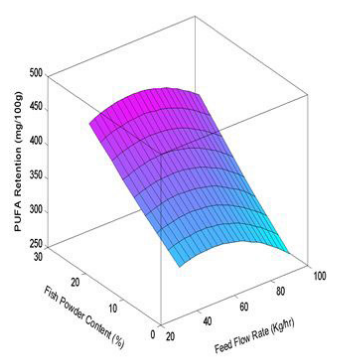

E

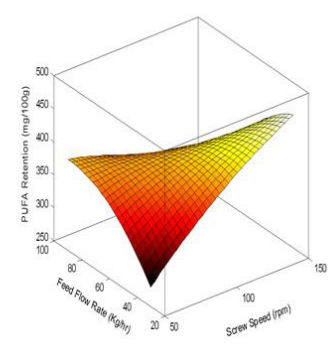

J

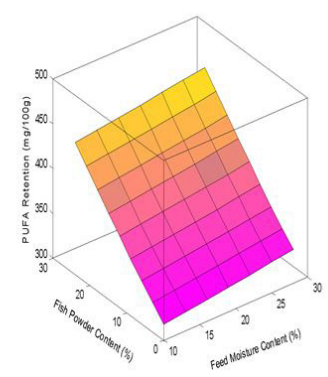

Figure 1. Mutual interaction effects of BET (100-150 $\left.{ }^{\circ} \mathrm{C}\right)$, SS (50-150 rpm), FFR (30-90 kg/hour), FMC (10-30\%) and FP (0-25\%) on PUFAs retention during thermal extrusion in functional macaroni production.

were observed in product extruded under BET $\left(125{ }^{\circ} \mathrm{C}\right)$, SS (100 rpm), FFR (60 kg/hr), FMC (30\%) and FP (25\%) for 0, 30 and 60 days of storage at $25^{\circ} \mathrm{C}$. The sensory evaluation score for products is shown in Table 5. The results for color, flavor and overall acceptability have shown that the product extruded at $125^{\circ} \mathrm{C} \mathrm{BET}, 150 \mathrm{rpm} \mathrm{SS}, 60 \mathrm{~kg} / \mathrm{hr}$ FFR, 20\% FMC and 25\% FP have the gain highest score (7.30 \pm 0.50 and $6.59 \pm 0.65)$, $(7.04 \pm 0.56,6.54 \pm 0.32)$ for color and flavor at 0 and 60 days storage, respectively. The product extruded at $125^{\circ} \mathrm{C}$ BET, $150 \mathrm{rpm} \mathrm{SS}, 60 \mathrm{~kg} / \mathrm{hr}$ FFR, 30\% FMC and 12.5\% FP have the best overall acceptability score.

\subsection{Discussion}

Fish and fish products are consumed as the major source of PUFAs, however, in low-income countries, due to high postharvest losses, this vital source of micronutrients and essential fatty acids are rarely available and affordable to the communities. In fishery sector, the post-harvest losses increases from 10 to 12 million tons per year also have a low shelf life (14-16 days) under ice storage condition (Nowsad et al., 2015). In Pakistan, most of the fish are consumed by roasting and frying technology that has few hours of storage that further leads to CVDs (Gadiraju et al., 2015). So this study was designed to use FP to develop fish powder supplemented macaroni with high PUFAs and better oxidative stability. Thus PUFAs optimized fished powder was obtained through MVD. In MVD the PUFAs non-significantly changed and remained unaffected from their original composition and contents. In MVD, due to a higher vacuum degree, the boiling temperature of the water is relatively lowered which results in easily drying of fish mince and could improve the quality of the finished product (Hearn et al., 1987). The addition of FP not only increases the PUFAs and MUFAs but also the protein contents of the final product in functional macaroni. The PUFAs and MUFAs increased from 0.4 to $0.64 \%$ and 0.1 to $0.74 \%$, respectively, providing a significant contribution to the recommended intakes of unsaturated fatty acids. Thus, extrusion processing plays an important role in the retention of PUFAs and MUFAs and their oxidative stability. It was reported that twin-screw extrusion with a high temperature of $180^{\circ} \mathrm{C}$ and a high SS of $300 \mathrm{rpm}$ did not significantly change the polyenoic fatty acids (Zadernowski et al., 1997). The BET, SS along FP addition have a highly significant effect on the retention of polyenoic fatty acids and particular PUFAs while FMC affects slight significance whereas the FFR does not significantly influence them. It can also be substantiated that the mutual influence of BET and FMC was slightly significant because the increase in BET at high FMC negatively affects the retention of PUFAs and MUFAs.

It was observed that SFAs significantly increased during the extrusion process. The higher temperature results in the conversion of double bonds from Cis to Trans fatty acids (Camire, 2000). These changes further occur during storage conditions leading to a change in the composition of fatty acids and oxidation of the product. It was observed that the better retention of TBARS values and carbonyl contents were detected in products with a high quantity of PUFAs and MUFAs. Changes in composition were rapid in the first 30 days as compared to the next 30 days of storage at $25^{\circ} \mathrm{C}$. Björck \& Asp (1983) also found that with the increase in an extrusion temperature decrease in fat content occurred and this statement is comparable to current findings. This might be due to the expulsion of fumes at higher temperatures from fats. So, the change in parameters like BET, SS, and FMC also affect the number of fats on different levels. BET and FMC are both the variables that mainly affect the composition retention and storage stability of PUFA's. Fitzpatrick et al. (2004) stated 
Table 4. Effect of thermal extrusion processing conditions on TRARS and carbonyl contents of product at $25^{\circ} \mathrm{C}$ for different storage intervals.

\begin{tabular}{|c|c|c|c|c|c|c|c|c|c|c|c|}
\hline \multirow{3}{*}{$\begin{array}{l}\text { Extrusion } \\
\text { processing } \\
\text { run }\end{array}$} & \multicolumn{5}{|c|}{ Independent variables } & \multirow{2}{*}{\multicolumn{3}{|c|}{$\begin{array}{c}\text { TBARS (mg MDA/kg) } \\
\text { Storage time (days) }\end{array}$}} & \multirow{2}{*}{\multicolumn{3}{|c|}{$\frac{\text { Carbonyl contents (nmol/mg protein) }}{\text { Storage time (days) }}$}} \\
\hline & \multirow{2}{*}{$\begin{array}{l}\text { Barrel } \\
\text { Exit } \\
\text { Temp. } \\
\text { (BET) }\end{array}$} & \multirow[b]{2}{*}{$\begin{array}{l}\text { Screw } \\
\text { Speed } \\
(\text { SS) }\end{array}$} & \multirow{2}{*}{$\begin{array}{l}\text { Feed } \\
\text { Flow } \\
\text { Rate } \\
\text { (FFR) }\end{array}$} & \multirow{2}{*}{$\begin{array}{c}\text { Feed } \\
\text { Moisture } \\
\text { Content } \\
\text { (FMC) }\end{array}$} & \multirow{2}{*}{$\begin{array}{c}\text { Fish } \\
\text { Powder } \\
\text { Content } \\
\text { (FP) }\end{array}$} & & & & & & \\
\hline & & & & & & 0 & 30 & 60 & 0 & 30 & 60 \\
\hline 1 & $150(1)$ & $150(1)$ & $60(0)$ & $20(0)$ & $12.5(0)$ & $0.27 \pm 0.01^{\mathrm{de}}$ & $0.29 \pm 0.02^{-3}$ & $0.34 \pm 0.02^{2}$ & $3.99 \pm 0.10$ & $5.64 \pm 0.05^{\mathrm{L}}$ & $7.27 \pm 0.19$ \\
\hline 2 & $125(0)$ & $150(1)$ & $60(0)$ & $20(0)$ & $25(1)$ & $42 \pm 0.04^{c}$ & $0.44 \pm 0.03^{\mathrm{bc}}$ & $0.51 \pm 0.07^{\mathrm{ab}}$ & $.91 \pm 0.15^{\mathrm{IJ}}$ & $7.56 \pm 0.08^{\mathrm{D}}$ & \\
\hline $3\left(C_{1}\right)$ & $125(0)$ & $00(0)$ & $60(0)$ & $0(0)$ & $2.5(0)$ & $26 \pm 0.02^{\mathrm{de}}$ & $.31 \pm 0.02^{\mathrm{d}}$ & $0.33 \pm 0.02^{\mathrm{d}}$ & $3.93 \pm 0.08^{R}$ & $5.54 \pm 0.12^{\mathrm{LM}}$ & $7.10 \pm 0.13^{\mathrm{FG}}$ \\
\hline 4 & $0(1)$ & $100(0)$ & $60(0)$ & $0(1)$ & $2.5(0)$ & $24 \pm 0.01^{\mathrm{e}}$ & $.26 \pm 0.01^{\mathrm{de}}$ & $0.30 \pm 0.04^{\mathrm{d}}$ & $4.08 \pm 0.09^{\mathrm{QR}}$ & $5.67 \pm 0.13^{\mathrm{KL}}$ & $7.32 \pm 0.11^{\mathrm{EF}}$ \\
\hline 5 & $100(-1)$ & 100 & $60(0)$ & & & $0 \pm 0.01^{\mathrm{fg}}$ & $11 \pm 0.01^{\mathrm{f}}$ & & & & \\
\hline \pm 6 & $100(-1)$ & $150(1)$ & $60(0)$ & (0) & $12.5(0)$ & $9 \pm 0.02^{\mathrm{de}}$ & $0.32 \pm 0.02^{\mathrm{d}}$ & $0.37 \pm 0.05^{\mathrm{cd}}$ & $3.87 \pm 0.08^{\mathrm{RS}}$ & $5.46 \pm 0.14^{\mathrm{M}}$ & $7.10 \pm 0.15^{\mathrm{FG}}$ \\
\hline 7 & $125(0)$ & $150(1)$ & $30(-1)$ & $20(0)$ & 12. & $8 \pm 0.02^{\mathrm{de}}$ & $0.31 \pm 0.04^{\mathrm{d}}$ & $0.35 \pm 0.07^{\mathrm{d}}$ & $4.12 \pm 0.11^{\mathrm{Q}}$ & $5.73 \pm 0.16^{\mathrm{K}}$ & $7.37 \pm 0.13^{\mathrm{E}}$ \\
\hline 08 & & $50(-1)$ & & & & $3 \pm 0.03^{e}$ & $5 \pm 0.01^{\mathrm{e}}$ & & & & \\
\hline 9 & & $100(0)$ & & & & & $0.10 \pm 0.01^{\mathrm{fg}}$ & & $3.11 \pm 0.10^{\mathrm{U}}$ & & $5.81 \pm 0.12^{\mathrm{JK}}$ \\
\hline 10 & (م) & $100(0)$ & $(0)$ & & (1) & $8 \pm 0.04^{\mathrm{cd}}$ & $0.41 \pm 0.04^{c}$ & $0.47 \pm 0.06^{\mathrm{b}}$ & $6.02 \pm 0.13^{\mathrm{I}}$ & $7.67 \pm 0.14^{\mathrm{CD}}$ & $37 \pm 0.15^{\mathrm{A}}$ \\
\hline 11 & $(0)$ & $100(0)$ & $90(1)$ & $-1)$ & 12. & $4 \pm 0.01^{\mathrm{e}}$ & $0.27 \pm 0.02^{\mathrm{de}}$ & $0.32 \pm 0.03^{\mathrm{d}}$ & $3.84 \pm 0.09^{\mathrm{s}}$ & & \\
\hline $12\left(C_{2}\right)$ & (0) & $100(0)$ & $0(0)$ & (0) & $12.5(0)$ & $27 \pm 0.05^{\mathrm{de}}$ & $0.30 \pm 0.03^{\mathrm{d}}$ & $0.33 \pm 0.02^{\mathrm{d}}$ & $3.90 \pm 0.12^{\mathrm{RS}}$ & $5.51 \pm 0.12^{\mathrm{LM}}$ & $7.11 \pm 0.16^{\mathrm{FG}}$ \\
\hline 13 & $125(0)$ & $150(1)$ & $60(0)$ & $30(1)$ & $125(0)$ & $29 \pm 0.02^{\mathrm{de}}$ & $0.31 \pm 0.01^{\mathrm{d}}$ & $025+10-d$ & $3.63 \pm 0.14^{\mathrm{T}}$ & & $6.89 \pm 0.12^{\mathrm{H}}$ \\
\hline 14 & & 100 & & & & & & 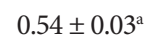 & & & \\
\hline 15 & & 100 & & & & & & & & & \\
\hline 16 & $-1)$ & 100 & (0) & 1) & 12.5 & $\pm 0.03^{\mathrm{de}}$ & $30 \pm 0.01^{\mathrm{d}}$ & $3 \pm 0$ & $3.77 \pm 0.09^{\mathrm{ST}}$ & $5.37 \pm 0.08^{\mathrm{MN}}$ & $7.03 \pm 0.09^{\mathrm{G}}$ \\
\hline 017 & & $100(0)$ & & & & & $22^{\mathrm{d}}$ & $4 \pm$ & & & \\
\hline 18 & & $100(0)$ & & & & & & & & & \\
\hline 19 & & 50 & & & & & $7 \pm$ & $9 \pm$ & & & \\
\hline 20 & & 100 & & & & & +8 & 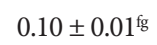 & & & \\
\hline 21 & & $100(0)$ & & & & & $\mathrm{cd}$ & & & & \\
\hline 0.22 & & $150(1)$ & & & & $\pm 0.01^{\mathrm{f}}$ & $0.13 \pm 0$ & $0.15 \pm 0$ & $2.98 \pm 0.12^{\mathrm{V}}$ & $2^{\mathrm{Q}}$ & \\
\hline 23 & & 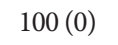 & & & & $01^{\mathrm{e}}$ & $5 \pm 0$ & $8 \pm$ & $3.78 \pm 0.13^{\mathrm{ST}}$ & $5.37 \pm$ & $7.04 \pm$ \\
\hline $24\left(C_{3}\right)$ & & 100 & & & 1 & $27 \pm 0.03^{\mathrm{de}}$ & $0.30 \pm 0.02^{\mathrm{d}}$ & $0.33 \pm 0.03^{\mathrm{d}}$ & $3.92 \pm 0.11^{\mathrm{R}}$ & $5.51 \pm 0.15^{\mathrm{LM}}$ & $7.09 \pm 0.21^{\mathrm{FG}}$ \\
\hline 25 & & & & & & & & & & & \\
\hline $26\left(C_{4}\right)$ & & $100(0)$ & $60(0)$ & & 12 & $26 \pm 0.03^{\mathrm{de}}$ & $0.31 \pm 0.03^{\mathrm{d}}$ & $0.34 \pm 0.04^{\mathrm{d}}$ & $3.91 \pm 0.09^{\mathrm{R}}$ & $5.51 \pm 0.11^{\mathrm{LM}}$ & $7.11 \pm 0.13^{\mathrm{FG}}$ \\
\hline 27 & & & & & & & & & & & \\
\hline 28 & & $150(1)$ & & & 12.5 & $3 \pm 0.02^{\mathrm{de}}$ & $0.32 \pm 0$ & & $3.84 \pm 0.13^{\mathrm{s}}$ & $5.45 \pm 0.14^{\mathrm{M}}$ & $0.17^{\mathrm{FG}}$ \\
\hline 29 & & 100 & & & & $8 \pm 0.03^{\text {cd }}$ & $0.43 \pm 0.05^{b c}$ & $055+505$ & $5.76 \pm 0.17^{\mathrm{K}}$ & $7.42 \pm 0.15^{\mathrm{DE}}$ & $9.12 \pm 0.19^{\mathrm{C}}$ \\
\hline 30 & & & & & & & $1^{\mathrm{fg}}$ & $1^{19}$ & & & $5.25 \pm 0.13^{\mathrm{N}}$ \\
\hline $31\left(\mathrm{C}_{5}\right)$ & & $100(0)$ & $60(0)$ & (0) & $12.5(0)$ & $26 \pm 0.03^{\mathrm{de}}$ & $0.30 \pm 0.03^{\mathrm{d}}$ & $0.34 \pm 0.05^{\mathrm{d}}$ & $3.91 \pm 0.14^{\mathrm{R}}$ & $5.51 \pm 0.10^{\mathrm{LM}}$ & $7.11 \pm 0.09^{\mathrm{FG}}$ \\
\hline 32 & & 100( & & & 12 & $\pm 0.02^{\mathrm{de}}$ & $0.29 \pm 0.02^{\mathrm{de}}$ & $3 \pm 0$ & & $.39 \pm 0.12^{\mathrm{MN}}$ & $0.16^{\mathrm{G}}$ \\
\hline 33 & & $100(0)$ & & & & $2 \pm 0.03^{\mathrm{d}}$ & $0.39 \pm 0.05^{\mathrm{cd}}$ & $0.48 \pm 0.04^{\mathrm{b}}$ & $5.97 \pm 0.18^{\mathrm{I}}$ & $7.63 \pm 0.11^{\mathrm{CD}}$ & $9.33 \pm 0.23^{\mathrm{AB}}$ \\
\hline 34 & & & & & & $\pm 0.05^{\mathrm{d}}$ & $37 \pm 0.03^{\mathrm{cd}}$ & $0.46 \pm 0.04^{\mathrm{b}}$ & $5.86 \pm 0.13^{\mathrm{J}}$ & $7.52 \pm 0.16^{\mathrm{D}}$ & $9.21 \pm 0.22^{\mathrm{BC}}$ \\
\hline 35 & & & & & & $5 \pm 0.01^{e}$ & $29 \pm 0.02^{\mathrm{de}}$ & $0.34 \pm 0.02^{\mathrm{d}}$ & $4.16 \pm 0.17^{Q}$ & $5.75 \pm 0.15^{\mathrm{K}}$ & $7.41 \pm 0.11^{\mathrm{DE}}$ \\
\hline 36 & $0(1)$ & $100(0)$ & $30(-1)$ & $20(0)$ & $12.5(0)$ & $6 \pm 0.02^{\mathrm{de}}$ & $0.29 \pm 0.01^{\mathrm{de}}$ & $0.35 \pm 0.04^{\mathrm{d}}$ & $4.22 \pm 0.09^{\mathrm{PQ}}$ & $5.82 \pm 0.14^{\top}$ & $7.48 \pm 0.09^{\mathrm{D}}$ \\
\hline 37 & & $100(0)$ & & & $12.5(0)$ & $25 \pm 0.02^{\mathrm{e}}$ & $0.28 \pm 0.01^{\mathrm{de}}$ & $0.33 \pm 0.02^{\mathrm{d}}$ & $4.30 \pm 0.10^{\mathrm{P}}$ & $5.92 \pm 0.18^{\mathrm{IJ}}$ & $7.60 \pm 0.11^{\mathrm{CD}}$ \\
\hline 38 & & & & & & $9 \pm 0.01^{\mathrm{fg}}$ & $10 \pm 0.01^{\mathrm{fg}}$ & $0.12 \pm 0.01^{\mathrm{f}}$ & $3.06 \pm 0.11^{\mathrm{UV}}$ & $4.26 \pm 0.09^{\mathrm{PQ}}$ & $5.81 \pm 0.12^{\mathrm{JK}}$ \\
\hline $39\left(C_{6}\right)$ & $125(0)$ & $100(0)$ & $60(0)$ & $20(0)$ & $12.5(0)$ & $0.27 \pm 0.01^{\mathrm{de}}$ & $0.31 \pm 0.02^{\mathrm{d}}$ & $0.34 \pm 0.03^{\mathrm{d}}$ & $3.89 \pm 0.10^{\mathrm{RS}}$ & $5.50 \pm 0.17^{\mathrm{LM}}$ & $7.10 \pm 0.18^{\mathrm{FG}}$ \\
\hline 40 & & $100(0)$ & $60(0)$ & (0) & $25(1)$ & $0.37 \pm 0.02^{\mathrm{cd}}$ & $0.42 \pm 0.05^{c}$ & $0.54 \pm 0.04^{\mathrm{a}}$ & $5.92 \pm 0.18^{\text {II }}$ & $7.58 \pm 0.09^{\mathrm{CD}}$ & $9.28 \pm 0.22^{\mathrm{B}}$ \\
\hline 41 & $125(0)$ & $150(1)$ & $90(1)$ & $20(0)$ & $12.5(0)$ & $0.28 \pm 0.03^{\mathrm{de}}$ & $0.30 \pm 0.01^{\mathrm{d}}$ & $0.33 \pm 0.02^{\mathrm{d}}$ & $3.73 \pm 0.16^{\mathrm{ST}}$ & $5.34 \pm 0.13^{\mathrm{N}}$ & $6.99 \pm 0.12^{\mathrm{GH}}$ \\
\hline 42 & $150(1)$ & $50(-1)$ & $60(0)$ & $20(0)$ & $12.5(0)$ & $0.22 \pm 0.01^{\mathrm{ef}}$ & $0.25 \pm 0.02^{\mathrm{e}}$ & $0.29 \pm 0.05^{\text {de }}$ & $4.41 \pm 0.11^{\mathrm{O}}$ & $6.01 \pm 0.12^{\mathrm{I}}$ & $7.67 \pm 0.13^{\mathrm{CD}}$ \\
\hline 43 & & $50(-1)$ & $30(-1)$ & $20(0)$ & $12.5(0)$ & $0.24 \pm 0.02^{\mathrm{e}}$ & $0.27 \pm 0.01^{\mathrm{de}}$ & $0.30 \pm 0.02^{\mathrm{d}}$ & $4.17 \pm 0.14^{\mathrm{Q}}$ & $5.78 \pm 0.14^{\mathrm{K}}$ & $7.43 \pm 0.17^{\mathrm{DE}}$ \\
\hline 44 & $125(0)$ & $100(0)$ & $30(-1)$ & $10(-1)$ & $12.5(0)$ & $0.26 \pm 0.01^{\mathrm{de}}$ & $0.29 \pm 0.03^{\mathrm{de}}$ & $0.33 \pm 0.04^{\mathrm{d}}$ & $4.02 \pm 0.17^{\mathrm{R}}$ & $5.63 \pm 0.13^{\mathrm{L}}$ & $7.27 \pm 0.10^{\mathrm{EF}}$ \\
\hline 45 & $125(0)$ & $100(0)$ & $30(-1)$ & $30(1)$ & $12.5(0)$ & $0.25 \pm 0.02^{e}$ & $0.28 \pm 0.01^{\mathrm{de}}$ & $0.32 \pm 0.02^{\mathrm{d}}$ & $3.82 \pm 0.10^{\mathrm{s}}$ & $5.43 \pm 0.19^{\mathrm{MN}}$ & $7.08 \pm 0.19^{\mathrm{FG}}$ \\
\hline 46 & $125(0)$ & $50(-1)$ & $60(0)$ & $30(1)$ & $12.5(0)$ & $.22 \pm 0.01^{\mathrm{ef}}$ & $0.24 \pm 0.02^{\mathrm{e}}$ & $0.28 \pm 0.01^{\text {de }}$ & $4.04 \pm 0.11^{\mathrm{QR}}$ & $5.63 \pm 0.17^{\mathrm{L}}$ & $7.29 \pm 0.20^{\mathrm{EF}}$ \\
\hline
\end{tabular}

$\mathrm{C}_{1}, \mathrm{C}_{2}, \mathrm{C}_{3}, \mathrm{C}_{4}, \mathrm{C}_{5}, \mathrm{C}_{6}$ are the center points where extrusion processing was applied. Values with same superscript letters (a-fg) show the homogenous group within the rows and columns for TBARS values $(p \leq 0.05)$. Values with same superscript letters $\left.{ }^{A-V}\right)$ show the homogenous group within the rows and columns carbonyl contents $(\mathrm{p} \leq 0.05)$. BET $=$ Barrel Exit Temp; SS $=$ Screw Speed; FFR = Feed Flow Rate; FMC = Feed Moisture Content; FP = Fish Powder; TBARS = Thiobarbituric acid reactive substance; MDA= malondialdehyde. 
Table 5. Effect of thermal extrusion processing conditions on the sensory attributes of product at $25^{\circ} \mathrm{C}$ during storage intervals.

\begin{tabular}{|c|c|c|c|c|c|c|c|c|c|c|c|}
\hline \multirow{3}{*}{$\begin{array}{c}\text { Extrusion } \\
\text { processing } \\
\text { run }\end{array}$} & \multicolumn{5}{|c|}{ Independent variables } & \multicolumn{6}{|c|}{ Sensory attributes } \\
\hline & \multirow{2}{*}{$\begin{array}{c}\text { Barrel } \\
\text { Exit } \\
\text { Temp. } \\
\text { (BET) }\end{array}$} & \multirow[b]{2}{*}{$\begin{array}{l}\text { Screw } \\
\text { Speed } \\
(\mathrm{SS})\end{array}$} & \multirow{2}{*}{$\begin{array}{l}\text { Feed } \\
\text { Flow } \\
\text { Rate } \\
\text { (FFR) }\end{array}$} & \multirow{2}{*}{$\begin{array}{c}\text { Feed } \\
\text { Moisture } \\
\text { Content } \\
(\text { FMC }) \\
\end{array}$} & \multirow{2}{*}{$\begin{array}{c}\text { Fish } \\
\text { Powder } \\
\text { Content } \\
\text { (FP) }\end{array}$} & \multicolumn{2}{|c|}{ Color } & \multicolumn{2}{|c|}{ Flavor } & \multicolumn{2}{|c|}{ Overall acceptability } \\
\hline & & & & & & 0 & 60 & 0 & 60 & 0 & 60 \\
\hline 1 & $150(1)$ & $150(1)$ & $60(0)$ & $20(0)$ & $12.5(0)$ & $6.92 \pm 0.43^{b c}$ & $0.22 \pm 0.39^{\circ}$ & $6.33 \pm 0.37^{\mathrm{de}}$ & $5.73 \pm 0.45^{\text {gh }}$ & $6.80 \pm 0.40^{\mathrm{b}}$ & $0.21 \pm 0.65$ \\
\hline 2 & $125(0)$ & $150(1)$ & $60(0)$ & $20(0)$ & $25(1)$ & $7.30 \pm 0.50^{\mathrm{a}}$ & $6.59 \pm 0.65^{\mathrm{d}}$ & $7.04 \pm 0.56^{\mathrm{a}}$ & $6.54 \pm 0.32^{c}$ & $6.44 \pm 0.81^{\mathrm{cd}}$ & $5.91 \pm 0.45^{\mathrm{f}}$ \\
\hline $3\left(C_{1}\right)$ & $125(0)$ & $100(0)$ & $60(0)$ & $0(0)$ & $2.5(0)$ & $.20 \pm 0.37^{\mathrm{fg}}$ & $5.60 \pm 0.48^{\mathrm{i}}$ & $6.28 \pm 0.45^{\mathrm{de}}$ & $5.79 \pm 0.60^{\mathrm{gh}}$ & $6.84 \pm 0.65^{\mathrm{ab}}$ & $6.25 \pm 0.36^{\mathrm{de}}$ \\
\hline 4 & $150(1)$ & $100(0)$ & $60(0)$ & $30(1)$ & $2.5(0)$ & $.30 \pm 0.39^{\mathrm{ef}}$ & $5.66 \pm 0.55^{\mathrm{i}}$ & $6.25 \pm 0.33^{e}$ & $5.71 \pm 0.56^{\mathrm{gh}}$ & $6.77 \pm 0.45^{\mathrm{b}}$ & $6.22 \pm 0.74^{\mathrm{de}}$ \\
\hline 5 & $100(-1)$ & $100(0)$ & & & $0(-1)$ & $33 \pm 0.31^{\mathrm{jk}}$ & $4.91 \pm 0.27^{\mathrm{lm}}$ & $5.82 \pm 025^{\mathrm{g}}$ & $5.45 \pm 0.35^{\mathrm{i}}$ & $6.44 \pm$ & \\
\hline 6 & $100(-1)$ & $150(1)$ & $60(0)$ & $20(0)$ & $12.5(0)$ & $6.73 \pm 0.45^{\mathrm{cd}}$ & $6.17 \pm 0.43^{\mathrm{fg}}$ & $6.29 \pm 0.47^{\mathrm{de}}$ & $5.83 \pm 0.55^{\mathrm{g}}$ & $6.82 \pm 0.70^{\mathrm{ab}}$ & $6.37 \pm 0.71^{\mathrm{d}}$ \\
\hline 7 & $125(0)$ & $150(1)$ & $30(-1)$ & $20(0)$ & $12.5(0)$ & $39 \pm 0.43^{\mathrm{ef}}$ & $5.88 \pm 0.54^{\mathrm{h}}$ & $6.46 \pm 0.55^{\mathrm{cd}}$ & $6.05 \pm 0.45^{\mathrm{f}}$ & $6.93 \pm 0.74^{\mathrm{a}}$ & $6.51 \pm 0.47^{\mathrm{cd}}$ \\
\hline 8 & & $50(-1)$ & & & $12.5(0)$ & $\pm 0.38^{\mathrm{fg}}$ & $5.41 \pm 0.60^{j}$ & $6.21 \pm 0.38^{\mathrm{e}}$ & $2 \pm 0.60^{\mathrm{h}}$ & $.72 \pm 0.58^{\mathrm{bc}}$ & $6.13 \pm 0.52^{\mathrm{e}}$ \\
\hline 9 & $150(1)$ & $100(0)$ & 60 & & & & $4.72 \pm 0.42^{\mathrm{m}}$ & $5.94 \pm 0.40^{\mathrm{fg}}$ & $5.51 \pm 0.45^{\mathrm{hi}}$ & $6.43 \pm 0.56^{\mathrm{cd}}$ & $6.02 \pm 0.26^{\text {ef }}$ \\
\hline 10 & $125(0)$ & $100(0)$ & $60(0)$ & $30(1)$ & $25(1)$ & $7.10 \pm 0.55^{\mathrm{b}}$ & $6.43 \pm 0.71^{\mathrm{ef}}$ & $7.02 \pm 0.62^{\mathrm{a}}$ & $6.53 \pm 0.80^{c}$ & $6.36 \pm 0.66^{\mathrm{d}}$ & $5.87 \pm 0.45^{\mathrm{fg}}$ \\
\hline 11 & & $100(0)$ & & & 12.5 & $0 \pm 0.38^{\mathrm{fg}}$ & $5.47+0.48 j$ & $6.32 \pm 0.39^{\mathrm{de}}$ & $9 \pm 0.32^{\mathrm{gh}}$ & $6.79 \pm 0.65^{b}$ & $6.27 \pm 0.80^{\mathrm{de}}$ \\
\hline $12\left(C_{2}\right)$ & 1 & $100(0)$ & & & 1 & $6.18 \pm 0.88^{\mathrm{fg}}$ & $5.59 \pm 0.41^{\mathrm{ij}}$ & $6.34 \pm 0.46^{\mathrm{de}}$ & $5.87 \pm 0.34^{\mathrm{fg}}$ & & $6.37 \pm 0.96^{\mathrm{d}}$ \\
\hline 13 & & & & & & & & & & $5^{\mathrm{a}}$ & \\
\hline 14 & 1 & $100(0)$ & & & & & & & & $6.29 \pm 0.75^{\mathrm{de}}$ & $0.62^{\mathrm{gh}}$ \\
\hline 15 & 1 & $100(0)$ & 1) & 2 & $0(-1)$ & $0 \pm 0.96^{j}$ & $33^{1}$ & $5.91 \pm 0.96^{\mathrm{fg}}$ & $5.53 \pm 0.37^{\mathrm{hi}}$ & $6.59 \pm 0.58^{c}$ & $6.22 \pm 0.35^{\mathrm{de}}$ \\
\hline 16 & $100(-1)$ & $100(0)$ & & & 5 & & & $6.18 \pm 0.36^{\mathrm{ef}}$ & & $6.66 \pm 0.65^{b c}$ & \\
\hline 17 & & $100(0)$ & & & $12.5(0)$ & & & $6.23 \pm 0.48^{\mathrm{e}}$ & & $6.70 \pm 0.46^{\mathrm{bc}}$ & \\
\hline 18 & $150(1)$ & $100(0)$ & & & $12.5(0)$ & $0 \pm 0.39^{\mathrm{fg}}$ & $5.53 \pm 0.48^{\mathrm{ij}}$ & $6.22 \pm 0.88^{e}$ & $5.65 \pm 0.88^{\mathrm{h}}$ & $6.69 \pm 0.70^{b c}$ & $.09 \pm 0.27^{\mathrm{ef}}$ \\
\hline 19 & $5(0)$ & 50( & & & & $\pm 0.40^{\mathrm{k}}$ & $472+0$ & $5.85 \pm 0.28^{\mathrm{g}}$ & $5.43 \pm 0.52^{\mathrm{i}}$ & $6.52 \pm 0.51^{\mathrm{cd}}$ & \\
\hline 20 & & $100(0)$ & & & & & & & & $2^{c}$ & \\
\hline 21 & $125(0)$ & $100(0)$ & & & 25 & & & & & & \\
\hline 22 & $=(0)$ & 150 & 60 & 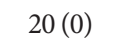 & 0 & $2 \pm 0.41^{j}$ & $5.01 \pm 0.50^{1}$ & $6.06 \pm 0.29^{\mathrm{ef}}$ & $5.67 \pm 0.96^{\mathrm{gh}}$ & $6.69 \pm 0.49^{b c}$ & $.29 \pm 0.52^{\mathrm{de}}$ \\
\hline 23 & & 100 & & & & & $4 \pm$ & $6.43 \pm$ & & & \\
\hline $24\left(C_{3}\right.$ & $125(0)$ & $100(0)$ & $60(0)$ & & 12.5 & $6.27 \pm 0.39^{f}$ & $5.80 \pm 0.56^{\mathrm{hi}}$ & $6.31 \pm 0.47^{\mathrm{de}}$ & $5.96 \pm 0.54^{\mathrm{fg}}$ & $6.84 \pm 0.72^{\mathrm{ab}}$ & $6.45 \pm 0.84^{\mathrm{cd}}$ \\
\hline 25 & 100( & $100(0)$ & & & 12.5 & & & $6.16 \pm 0.88^{\mathrm{ef}}$ & $5.80 \pm 0.36^{\mathrm{gh}}$ & $6.68 \pm$ & \\
\hline $26\left(C_{4}\right)$ & $125(0)$ & $100(0)$ & $60(0)$ & 0) & $12.5(0)$ & $6.21 \pm 0.34^{\mathrm{fg}}$ & $5.54 \pm 0.96^{\mathrm{ij}}$ & $6.35 \pm 0.96^{\mathrm{de}}$ & $5.78 \pm 0.54^{\text {gh }}$ & $6.75 \pm 0.62^{\mathrm{b}}$ & $6.23 \pm 0.69^{\mathrm{de}}$ \\
\hline 27 & & $50(-1)$ & & & & & & & & $6.73 \pm 0.58^{b c}$ & \\
\hline 28 & 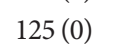 & $150(1)$ & & & $12.5(0)$ & $7 \pm 0.43^{\text {ef }}$ & $5.89 \pm 0.55^{\mathrm{h}}$ & $6.41 \pm 0.39^{\mathrm{d}}$ & $6.02 \pm 0.51^{\mathrm{f}}$ & $6.91 \pm 0.65^{\mathrm{ab}}$ & $6.51 \pm 0.85^{\mathrm{cd}}$ \\
\hline 29 & $125(0)$ & $100(0)$ & & 20 & $25(1)$ & $0 \pm 0.96^{c}$ & $6.14 \pm 0.66^{\mathrm{fg}}$ & $6.89 \pm 0.66^{\mathrm{ab}}$ & $6.33 \pm 0.69^{\text {de }}$ & $6.33 \pm 0.55^{\mathrm{d}}$ & $5.78 \pm 0.37^{g}$ \\
\hline 30 & & $100(0)$ & & & & $7 \pm 0.43^{j}$ & & $6.04 \pm 0.34^{\mathrm{f}}$ & $5.67 \pm 0.49^{\text {gh }}$ & $6.64 \pm 0.60^{\mathrm{bc}}$ & $6.27 \pm 0.64^{\mathrm{de}}$ \\
\hline $31\left(C_{5}\right)$ & $125(0)$ & $100(0)$ & $60(0)$ & $20(0)$ & $2.5(0)$ & $6.33 \pm 0.41^{\mathrm{ef}^{\mathrm{f}}}$ & $5.80 \pm 0.36^{\mathrm{hi}}$ & $6.29 \pm 0.47^{\mathrm{de}}$ & $5.87 \pm 0.96^{\mathrm{fg}}$ & $6.83 \pm 0.51^{\mathrm{ab}}$ & $6.41 \pm 0.38^{\mathrm{cd}}$ \\
\hline 32 & $100(-1)$ & $100(0)$ & & & $12.5(0)$ & & $6.11 \pm 0.47^{\mathrm{fg}}$ & $6.23 \pm 0.37^{\mathrm{e}}$ & $5.82 \pm 0.54^{\mathrm{g}}$ & $6.74 \pm 0.88^{b c}$ & $6.33 \pm 0.90^{\mathrm{d}}$ \\
\hline 33 & & $100(0)$ & & & & $75 \pm 0.63^{\mathrm{cd}}$ & $6.08 \pm 0.59^{g}$ & $6.79 \pm 0.61^{\mathrm{b}}$ & $6.31 \pm 0.75^{\mathrm{de}}$ & $6.21 \pm 0.96^{\mathrm{de}}$ & $5.72 \pm 0.73^{\mathrm{gh}}$ \\
\hline 34 & & $50(-1)$ & & & & & $5.91 \pm 0$ & $6.87 \pm 0.57^{\mathrm{ab}}$ & & $6.24 \pm 0.79^{\mathrm{de}}$ & $5.74 \pm 0.18^{g}$ \\
\hline 35 & $100(-1)$ & $50(-1)$ & & & $12.5(0)$ & & $5.75 \pm 0.96^{\mathrm{hi}}$ & $6.12 \pm 0.33^{\mathrm{ef}}$ & $5.67 \pm 0.37^{\text {gh }}$ & $6.61 \pm 0.70^{\mathrm{bc}}$ & $6.16 \pm 0.88^{e}$ \\
\hline 36 & $150(1)$ & $100(0)$ & $30(-1)$ & & $12.5(0)$ & $6.22 \pm 0.46^{\mathrm{fg}}$ & $5.56 \pm 0.43^{\mathrm{ij}}$ & $6.20 \pm 0.45^{\mathrm{ef}}$ & $5.64 \pm 0.39^{\mathrm{h}}$ & $6.72 \pm 0.47^{b c}$ & $6.17 \pm 0.58^{\mathrm{e}}$ \\
\hline 37 & $150(1)$ & $100(0)$ & $60(0)$ & & $12.5(0)$ & $5.11 \pm 0.40^{\mathrm{fg}}$ & $5.49 \pm 0.39^{\mathrm{ij}}$ & $6.14 \pm 0.50^{\mathrm{ef}}$ & $5.61 \pm 0.51^{\mathrm{h}}$ & $6.64 \pm 0.63^{b c}$ & $6.18 \pm 0.61^{\mathrm{e}}$ \\
\hline 38 & & $100(0)$ & & & & & & $5.82 \pm 0.37^{\mathrm{g}}$ & $5.53 \pm 0.36^{\mathrm{hi}}$ & $6.61 \pm 0.54^{\mathrm{bc}}$ & $6.32 \pm 0.49^{\mathrm{de}}$ \\
\hline $39\left(C_{6}\right)$ & $125(0)$ & $100(0)$ & $60(0)$ & $20(0)$ & $12.5(0)$ & $6.07 \pm 0.38^{g}$ & $5.46 \pm 0.51^{j}$ & $6.35 \pm 0.91^{\mathrm{de}}$ & $5.85 \pm 0.50^{\mathrm{g}}$ & $6.87 \pm 0.69^{\mathrm{ab}}$ & $6.32 \pm 0.83^{\mathrm{de}}$ \\
\hline 40 & $100(-1)$ & $100(0)$ & $60(0)$ & $20(0)$ & $25(1)$ & $6.81 \pm 0.88^{\mathrm{cd}}$ & $6.11 \pm 0.91^{\mathrm{fg}}$ & $6.82 \pm 0.67^{\mathrm{b}}$ & $6.31 \pm 0.67^{\text {de }}$ & $6.21 \pm 0.60^{\text {de }}$ & $5.73 \pm 0.46^{g}$ \\
\hline 41 & $125(0)$ & $150(1)$ & $90(1)$ & $20(0)$ & $12.5(0)$ & $6.47 \pm 0.45^{\mathrm{e}}$ & $5.96 \pm 0.50^{\mathrm{gh}}$ & $6.46 \pm 0.51^{\mathrm{cd}}$ & $6.05 \pm 0.44^{\mathrm{f}}$ & $6.94 \pm 0.67^{\mathrm{a}}$ & $6.50 \pm 0.74^{c d}$ \\
\hline 42 & $150(1)$ & $50(-1)$ & $60(0)$ & $20(0)$ & $12.5(0)$ & $6.42 \pm 0.37^{\mathrm{ef}}$ & $5.81 \pm 0.54^{\mathrm{hi}}$ & $6.11 \pm 0.35^{\mathrm{ef}}$ & $5.59 \pm 0.88^{\mathrm{hi}}$ & $6.59 \pm 0.61^{c}$ & $6.06 \pm 0.39^{\mathrm{ef}}$ \\
\hline 43 & $125(0)$ & $50(-1)$ & $30(-1)$ & $20(0)$ & $12.5(0)$ & $6.02 \pm 0.91^{\mathrm{gh}}$ & $5.45 \pm 0.38^{j}$ & $6.27 \pm 0.44^{\mathrm{de}}$ & $5.81 \pm 0.49 \mathrm{~g}$ & $6.72 \pm 0.57^{b c}$ & $6.23 \pm 0.62^{\mathrm{de}}$ \\
\hline 44 & $125(0)$ & $100(0)$ & $30(-1)$ & $10(-1)$ & $12.5(0)$ & $6.14 \pm 0.88^{\mathrm{fg}}$ & $5.62 \pm 0.44^{\mathrm{i}}$ & $6.23 \pm 0.32^{\mathrm{e}}$ & $5.82 \pm 0.51^{g}$ & $6.79 \pm 0.52^{b}$ & $6.36 \pm 0.38^{\mathrm{d}}$ \\
\hline 45 & $125(0)$ & $100(0)$ & $30(-1)$ & $30(1)$ & $12.5(0)$ & $6.35 \pm 0.44^{\mathrm{ef}}$ & $5.90 \pm 0.52^{\mathrm{gh}}$ & $6.36 \pm 0.48^{\mathrm{de}}$ & $6.02 \pm 0.55^{\mathrm{f}}$ & $6.92 \pm 0.71^{\mathrm{a}}$ & $6.57 \pm 0.88^{c}$ \\
\hline 46 & $125(0)$ & $50(-1)$ & $60(0)$ & $30(1)$ & $12.5(0)$ & $6.13 \pm 0.37^{\mathrm{fg}}$ & $5.54 \pm 0.54^{\mathrm{ij}}$ & $6.31 \pm 0.88^{\mathrm{de}}$ & $5.83 \pm 0.60^{\mathrm{g}}$ & $6.80 \pm 0.66^{\mathrm{b}}$ & $6.31 \pm 0.91^{\mathrm{de}}$ \\
\hline
\end{tabular}

$\mathrm{C}_{1}, \mathrm{C}_{2}, \mathrm{C}_{3}, \mathrm{C}_{4}, \mathrm{C}_{5}, \mathrm{C}_{6}$ are the center points where extrusion processing was applied. Different superscripts letters indicate the significance $(\mathrm{p} \leq 0.05)$ within for color, flavor and overall acceptability. BET = Barrel Exit Temp; SS = Screw Speed; FFR = Feed Flow Rate; FMC = Feed Moisture Content; FP = Fish Powder. 
that storage conditions may influence the levels of fat and the same results are noticed in this study. With the change in BET, SS and FMC also change the levels of fat. The high temperature not only inactivates the lipase enzymes but also facilities the binding of lipids with carbohydrates contents that ultimately affect the oxidative stability of lipid in extruded products (Thachil et al., 2014).

\section{Conclusion}

The moderate BET $\left(125^{\circ} \mathrm{C}\right)$ with high SS $(150 \mathrm{rpm})$, moderate FMC (20\%), and high FP (25\%) facilitate the highest retention of PUFAs and MUFAs in end products. The Highest PUFAs retention for short time storage takes place in product extruded at moderate BET with moderate SS high FFR and moderate FP. Moderate conditions have been recommended as the best option for good quality products with maximum retention of long-chain PUFAs and MUFAs and storage stability. Moreover, results from this work will aid in the formulation of healthier food products supplemented with fish dried powder and may address a critical industrial demand in terms of formulation options. Further studies can be conducted to determine the maximal shelf life of products supplemented with fish PUFAs along with protein for value addition and treatment of nutritional disorders through their absorption, metabolism, and distribution pattern into biological tissues.

\section{References}

Ab Latif Wani, S. A. B., \& Ara, A. (2015). Omega-3 fatty acids and the treatment of depression: a review of scientific evidence. Integrative Medicine Research, 4(3), 132-141. http://dx.doi.org/10.1016/j. imr.2015.07.003. PMid:28664119.

Ahmad, N., Manzoor, M. F., Shabbir, U., Ahmed, S., Ismail, T., Saeed, F., Nisa, M., Anjum, F. M., \& Hussain, S. (2019). Health lipid indices and physicochemical properties of dual fortified yogurt with extruded flaxseed omega fatty acids and fibers for hypercholesterolemic subjects. Food Science \& Nutrition, 8(1), 273-280. http://dx.doi. org/10.1002/fsn3.1302. PMid:31993153.

Berger, M., Smesny, S., Kim, S., Davey, C., Rice, S., Sarnyai, Z., Schlögelhofer, M., Schäfer, M. R., Berk, M., McGorry, P. D., \& Amminger, G. P. (2017). Omega-6 to omega-3 polyunsaturated fatty acid ratio and subsequent mood disorders in young people with at-risk mental states: a 7-year longitudinal study. Translational Psychiatry, 7(8), e1220. http://dx.doi.org/10.1038/tp.2017.190. PMid:28850110.

Björck, I., \& Asp, N.-G. (1983). The effects of extrusion cooking on nutritional value: a literature review. Journal of Food Engineering, 2(4), 281-308. http://dx.doi.org/10.1016/0260-8774(83)90016-X.

Camire, M. E. (2000). Chemical and nutritional changes in food during extrusion. In M. N. Riaz (Ed.), Extruders in food applications (pp. 127-147). Boca Raton: CRC Press.

Carvalho, A. P., \& Malcata, F. X. (2005). Preparation of fatty acid methyl esters for gas-chromatographic analysis of marine lipids: insight studies. Journal of Agricultural and Food Chemistry, 53(13), 5049-5059. http://dx.doi.org/10.1021/jf048788i. PMid:15969474.

Civille, G. V., \& Carr, B. T. (2015). Sensory evaluation techniques. Boca Raton: CRC Press. http://dx.doi.org/10.1201/b19493.

Cui, Z.-W., Sun, L.-J., Chen, W., \& Sun, D.-W. (2008). Preparation of dry honey by microwave-vacuum drying. Journal of Food Engineering, 84(4), 582-590. http://dx.doi.org/10.1016/j.jfoodeng.2007.06.027.
Fitzpatrick, J., Iqbal, T., Delaney, C., Twomey, T., \& Keogh, M. (2004). Effect of powder properties and storage conditions on the flowability of milk powders with different fat contents. Journal of Food Engineering, 64(4), 435-444. http://dx.doi.org/10.1016/j.jfoodeng.2003.11.011.

Fu, V., Plouffe, S. W., \& Guan, K.-L. (2017). The Hippo pathway in organ development, homeostasis, and regeneration. Current Opinion in Cell Biology, 49, 99-107. http://dx.doi.org/10.1016/j.ceb.2017.12.012. PMid:29316535.

Gadiraju, T. V., Patel, Y., Gaziano, J. M., \& Djoussé, L. (2015). Fried food consumption and cardiovascular health: a review of current evidence. Nutrients, 7(10), 8424-8430. http://dx.doi.org/10.3390/ nu7105404. PMid:26457715.

Hearn, T. L., Sgoutas, S. A., Sgoutas, D. S., \& Hearn, J. A. (1987). Stability of polyunsaturated fatty acids after microwave cooking of fish. Journal of Food Science, 52(5), 1430-1431. http://dx.doi. org/10.1111/j.1365-2621.1987.tb14100.x.

Imran, M., \& Anjum, F. M. (2014). Influence of twin-screw hot extrusion on linolenic acid retention in flaxseed meal. Pakistan Journal of Agricultural Sciences, 51(1), 161-166.

Kouba, M., \& Mourot, J. (2011). A review of nutritional effects on fat composition of animal products with special emphasis on $n-3$ polyunsaturated fatty acids. Biochimie, 93(1), 13-17. http://dx.doi. org/10.1016/j.biochi.2010.02.027. PMid:20188790.

Li, Y., Xu, S.-Y., \& Sun, D.-W. (2007). Preparation of garlic powder with high allicin content by using combined microwave-vacuum and vacuum drying as well as microencapsulation. Journal of Food Engineering, 83(1), 76-83. http://dx.doi.org/10.1016/j.jfoodeng.2007.02.057.

Memon, N. N., Talpur, F. N., Bhanger, M., \& Balouch, A. (2011). Changes in fatty acid composition in muscle of three farmed carp fish species (Labeo rohita, Cirrhinus mrigala, Catla catla) raised under the same conditions. Food Chemistry, 126(2), 405-410. http:// dx.doi.org/10.1016/j.foodchem.2010.10.107.

Montgomery, D. (1991). Response surface methods and designs. In D. Montgomery, Design and analysis of experiments. New York: Wiley.

Nowsad, A. A., Hossain, M., Hassan, M., Sayem, S., \& Polanco, J. F. (2015). Assessment of post harvest loss of wet fish: a novel approach based on sensory indicator assessment. SAARC Journal of Agriculture, 13(1), 75-89. http://dx.doi.org/10.3329/sja.v13i1.24182.

Ogbobe, O., \& Akano, V. (1993). The physico-chemical properties of the seed and seed oil offatropha gossipifolia. Plant Foods for Human Nutrition, 43(3), 197-200. http://dx.doi.org/10.1007/BF01886220. PMid:8506234.

Patterson, E., Wall, R., Fitzgerald, G., Ross, R., \& Stanton, C. (2012). Health implications of high dietary omega- 6 polyunsaturated fatty acids. Journal of Nutrition and Metabolism, 2012, 539426. http:// dx.doi.org/10.1155/2012/539426. PMid:22570770.

Shahzad, M. A., Ahmad, N., Ismail, T., Manzoor, M. F., Ismail, A., Ahmed, N., \& Akhtar, S. (2020). Nutritional composition and quality characterization of lotus (Nelumbo nucifera Gaertn.) seed flour supplemented cookies. Journal of Food Measurement and Characterization, 1-8.

Shaviklo, G. R., Olafsdottir, A., Sveinsdottir, K., Thorkelsson, G., \& Rafipour, F. (2011). Quality characteristics and consumer acceptance of a high fish protein puffed corn-fish snack. Journal of Food Science and Technology, 48(6), 668-676. http://dx.doi.org/10.1007/s13197010-0191-1. PMid:23572803.

Shaviklo, G. R., Thorkelsson, G., Arason, S., \& Sveinsdottir, K. (2012). Characteristics of freeze-dried fish protein isolated from saithe (Pollachius virens). Journal of Food Science and Technology, 49(3), 309318. http://dx.doi.org/10.1007/s13197-011-0285-4. PMid:23729850. 
Shaviklo, G. R., Thorkelsson, G., Sveinsdottir, K., \& Pourreza, F. (2013). Studies on processing, consumer survey and storage stability of a ready-to-reconstitute fish cutlet mix. Journal of Food Science and Technology, 50(5), 900-908. http://dx.doi.org/10.1007/s13197-0110417-x. PMid:24425996.

Silva, G. F., Rocha, L. W., \& Quintão, N. L. M. (2015). Nutraceuticals, dietary supplements, and functional foods as alternatives for the relief of neuropathic pain. In R. R. Watson \& V. R. Preedy (Eds.), Bioactive nutraceuticals and dietary supplements in neurological and brain disease (pp. 87-93). London: Elsevier. http://dx.doi.org/10.1016/ B978-0-12-411462-3.00010-2.

Singh, S., Gamlath, S., \& Wakeling, L. (2007). Nutritional aspects of food extrusion: a review. International Journal of Food Science \& Technology, 42(8), 916-929. http://dx.doi.org/10.1111/j.13652621.2006.01309.x.

Thachil, M. T., Chouksey, M. K., \& Gudipati, V. (2014). Amylose-lipid complex formation during extrusion cooking: effect of added lipid type and amylose level on corn-based puffed snacks. International Journal of Food Science \& Technology, 49(2), 309-316. http://dx.doi. org/10.1111/ijfs.12333.

Wang, K., Li, C., Wang, B., Yang, W., Luo, S., Zhao, Y., Jiang, S., Mu, D., \& Zheng, Z. (2017). Formation of macromolecules in wheat gluten/ starch mixtures during twin-screw extrusion: effect of different additives. Journal of the Science of Food and Agriculture, 97(15), 5131-5138. http://dx.doi.org/10.1002/jsfa.8392. PMid:28429501.

Zadernowski, R., Nowak-Polakowska, H., Wicklund, T., \& Fornal, Ł. (1997). Changes in oat lipids affected by extrusion. Food, 41(4), 224-227. http://dx.doi.org/10.1002/food.19970410408.

Zhang, Y., Liu, W., Liu, C., Luo, S., Li, T., Liu, Y., Wu, D., \& Zuo, Y. (2014). Retrogradation behaviour of high-amylose rice starch prepared by improved extrusion cooking technology. Food Chemistry, 158, 255-261. http://dx.doi.org/10.1016/j.foodchem.2014.02.072. PMid:24731339. 